\title{
Community libraries: the concept and its application by the Pinetown Public Library
}

\author{
B.J. Mostert ${ }^{\star} \&$ W.M. Vermeulen \\ Department of Library and Information Science, University of Zululand, Private Bag X1001, KwaDlangezwa \\ 3886 Republic of South Africa
}

\begin{abstract}
Public libraries in South Africa have largely failed to address the information needs of developing communities. As a result the establishment of alternative library services, notably resource centres and community libraries, have gathered momentum since the 1980s. The concept of community libraries, currently embraced by an increasing number of public libraries, is explored, and the community library system implemented by the Pinetown Public Library is evaluated against norms derived from the literature on the development of public libraries in Africa and South Africa.
\end{abstract}

\begin{abstract}
Openbare biblioteke in Suid-Afrika het nie noemenswaardig daarin geslaag om dienste te voorsien wat die wesentlike behoeftes van ontwikkelende gemeenskappe aanspreek nie. Gevolglik het alternatiewe dienste soos byvoorbeeld bronnesentrums en gemeenskapsbiblioteke ontstaan, veral vanaf die vroeë tagtiger jare. Die konsep van gemeenskapsbiblioteke wat besig is om in openbare biblioteke veld te wen, word ontleed en die stelsel wat deur Pinetown se Openbare Biblioteek in werking gestel is, word geëvalueer aan die hand van norme gebaseer op die literatuur oor die ontwikkeling van openbare biblioteke in Afrika en Suid-Afrika.
\end{abstract}

*Author to whom correspondence should be addressed.

\section{Background}

African communities initially embraced public libraries, expecting them to support the educational and informational needs of the people, and to assist in the process of general upliftment and development of the disadvantaged. Contrary to these expectations public libraries did not flourish in spite of remarkable quantitative expansion experienced at first. Sturges and Neill (1990:71,73) blame this on a lack of research into the particular information needs of Africa which led to the establishment of services which had very little to offer the African people. Chijioke (1989:176) reports that libraries are not seen as significant role players in the process of national development, for example, a study conducted in Nigeria emphasised information as an important factor in development, but libraries were not assigned any role in the process. In South Africa Zaaiman, Roux \& Rykheer (1988:5) came to much the same conclusion. The literature therefore, not surprisingly, shows that existing library services are not extensively used. Less than $2 \%$ of the population in Tanzania and approximately $5 \%$ in Botswana use libraries (Mchombu 1991). In South Africa the 1996 figure was $8.8 \%$ of the total population which includes a significant component of users from developed communities (Mostert 1997:57).

Shera (1972:190) provides a sober perspective in this regard when he says public libraries, like all other social institutions are shaped by two forces: by the demands made on them by society and the changes in those demands resulting from social change; and by the objectives of the professional leaders in the field of librarianship. Conflict between these two forces could arise when the demands of society do not correspond with the objectives of the professional leaders, and when such conflict arises, it is the responsibility of the public library to resolve the conflict, for an institution that does not meet the social demands placed upon it, will ossify or decay, and be replaced.

Librarians on the African continent have for some time been concerned about the conflict between the needs of the people and the services provided. The reasons for the unsatisfactory performance of public libraries have been quite widely researched, and various alternatives to the Western library model which has been singled out as a major stumbling block, have been implemented. Tanzania, for example, introduced a system of bare-foot librarians with the libraries owned and controlled by the communities served (Banach 1989:10). Botswana launched the Village Reading Room Project in which the community took ownership of the building, materials and service, sometimes even erecting the buildings themselves (Raseroka 1994:6). In South Africa resource centres, being aligned to the progressive movement, were particularly successful during the apartheid years. Between 1984 and 1989, 93 resource centres were established (Stilwell 1992:214), while more recently community libraries have gained in popularity because of their commitment to empowerment of the entire community through their information service (Mostert 1997:82). Some public libraries in South Africa have displayed a tendency to adopt features common to community libraries. The Vosloorus Public Library has been so successful with its involvement of the community that Stilwell (1991b:268) regards it as representing the community library ideal in South Africa. The City of Pretoria 
named its new public library the Pretoria Community Library. The Pinetown Public Library claims more progress towards a community library than a mere change of name. It is a conventional public library system which is in the process of establishing community libraries as part of its main library system. The question which interested the research team was, whether the Pinetown community libraries were community libraries in the true sense of the word, or whether they were still conventional public libraries disguised as community libraries to follow the winds of change sweeping the country.

\section{Purpose of the study}

The purpose of the study was to identify the characteristics and possible weaknesses of public libraries, specifically in South Africa; to study trends with regard to community libraries and to establish norms for community libraries; to conduct a survey of the community libraries in the Borough of Pinetown, and to test the validity of these libraries against the norms established.

\section{Methodology}

The major steps followed in conducting the project were the following:

- A literature review of the development of public libraries in South Africa (and also the rest of the African continent) was conducted. The results were used to abstract verbal models to provide a basis for comparison and evaluation. Only models relevant to this article are included.

- A survey was conducted to collect information on the Pinetown community libraries. The survey involved two target groups: the librarians of the community libraries; and members of the communities served, users as well as non-users.

Interviews and self-administered questionnaires were used to collect information from the librarians. The questionnaires provided background material regarding the libraries and the services they provide, while the interviews were used to collect in-depth information with regard to specific aspects of the community libraries. Self-administered questionnaires were used to ascertain the communities' reaction to the community libraries (and libraries in general), and to determine whether the libraries served the purpose which the communities had in mind for them when they initially requested the facilities, namely to assist the school children and students in their school work, to nurture a reading culture and also to contribute to community activities.

Responses were received from ten community librarians (each library had two staff members), and 109 community members. The convenience method was used to select community respondents. Questionnaires were handed out to users who were available at the time when the Zulu-speaking field worker visited a specific library. All the questionnaires were distributed on the same day, and collected on that day before the users left the library. The field worker also remained on hand to assist respondents with questions which needed clarification. Questionnaires for non-users were distributed at a shopping centre in Pinetown South to the first 25 people willing to co-operate. The field worker collected the questionnaires as they were completed.

\section{Nature of public libraries}

Society creates institutions to provide for needs which are regarded as crucial for its survival. Six spheres of needs are commonly distinguished: the economy, religion, law, the family, politics and education, and the public library is regarded as part of the institution of education (Wilson 1977: 6 ). The manner in which to function as an educational agency has however posed problems for public libraries, resulting in several paradigm shifts. To achieve the most appropriate paradigm to meet the challenge of relevance to the demands of society, public libraries have at various times tried to play different roles, even attempting to be all things to all men which Martin (1989:18) ironically describes as a passive stage because this role requires social neutrality. By the early 1980 s shifts in roles, for example, from outreach to community librarianship, to community information centres left public librarians rather confused with regard to their professional identity because their many initiatives had still not provided the ideal solution. Williams (1988:137) and Astbury (1993:64-65) introduced some sanity into this confusion by a strong plea for the public library's identity to be restored to that of an institution for formal self-education. It should be left to perform the only task of importance it ever had, namely to provide education for those who seek it, adapting its educational role to changing circumstances.

In developing countries the public library's educational role is closely linked to support for development, a process during which the quality of human life is improved (Todaro 1989: 89-90). Cillié (1995:4) describes information as a strategic resource which contributes directly to socio-cultural, economic, scientific, technological and personal development, and which is indispensable for education and fulfilment of public life. Therefore it is a commodity from which the entire community must benefit. Zaaiman, Roux and Rykheer (1988: $35)$ as well as Kagan (1982:1) emphasize the role of libraries in disadvantaged communities with regard to educational and developmental work.

Table 1 provides a model showing the various positions occupied by the public library in society, and the roles it should play.

\section{Public library in South Africa}

Stilwell (1991b:237) identifies several problems which have plagued public libraries in Africa, as well as in South Africa. These basically all revolve around the application of, what she calls, the anachronistic and inappropriate Western model. The application of this model affected every aspect of public library provision: type of accommodation; collection development, and services (aimed at the literate sector of society which caused a late start with literacy programmes, 
Table 1 Nature of the public library

\begin{tabular}{ll}
\hline Institutional type & Characteristics \\
\hline Societal institution: & Society determines nature of service \\
& - Public library as societal institution: \\
& - Collects, organises, disseminates mankind's \\
& records for use; \\
& - Supports education and development by sup- \\
& plying information; \\
& - Society's judgement causes service to succeed, \\
& fail, or be replaced.
\end{tabular}

Educational institution:

Various forms of education are practised, and supported by public library:

- Informal education:

- Unsystematic and unorganised;

- Achieved through provision of information sources, exhibitions, lectures, demonstrations and cultural activities supported by libraries.

- Formal education:

- Planned and systematic;

- Library provides information complementing school and other curricula;

- Provides study space.

- Non-formal education:

- Organised, systematic activities taking place outside the school system;

- Orchestrated by a variety of organisations, and public and private bodies;

- Library arranges lectures and exhibitions and makes facilities available to organisations.

Developmental institution

Development implies improvement of quality of life:

- Information contributes to the improvement quality of life, i.e. development;

- Information services suit the developmental needs of local communities;

- Librarians identify themselves and their service with their communities;

- Libraries play a pro-active role in combating illiteracy, which hampers development of underdeveloped.

retarding the public library's entry into the development arena); inappropriate training of staff; and poor cooperation with other information agencies especially with regard to information for developmental purposes (Cillié 1995:2). Underlying most of these weaknesses is the lack of in-depth needs analysis. Fairer-Wessels and Machet
(1993:101) conclude that public libraries, also those established especially for Blacks, are neither reflecting, nor addressing the real needs of their communities. This corroborates Bekker and Lategan's earlier finding (1988:69) that by their nature urban libraries do not cater for the needs of the black community because people need to be advised, and need to be given the opportunity to ask questions. It is the awareness of the inadequate provision of library services to disadvantaged communities that led to the establishment of the alternative services referred to above.

Table 2 summarises the characteristics of the South African public library system as revealed by the literature.

\section{Community libraries}

A community library means different things to different people and its services will differ according to the needs of specific communities. The literature therefore attributes a variety of characteristics to community libraries.

Community libraries differ from public libraries in that they are established at the request of the community, and are maintained and funded through resources made available by the community. Community libraries need to be established with the full co-operation of the local population. Consultation with accepted leaders in the community should be used to establish the nature of the service expected. Stilwell (in South African libraries must adapt or die, 1991:6) advocates participative research and participative management as methods for ascertaining the needs of the community. An important aspect that needs to be taken into account is the existing information networks in the community, so as to harness, and not compete with them.

The social purpose of these libraries differs markedly from those of the public library. While the public library is passive about its sense of social purpose, community libraries are pro-active. In community libraries neutrality of service is seen as neither possible nor desirable.

Community libraries should be accessible to all members of the community, regardless of social standing. Coleman (in Barnes 1994:79) describes these services as highly political by nature in the sense that everybody should have the right to equal access of information and society's resources. This is also a characteristic that distinguishes the community library from other information services. Expensive buildings do not have to be the norm for housing these libraries. According to Stilwell (in South African libraries must adapt or die, 1991:6) small, cheap units, in close proximity to the people's abodes, can be used.

Information provided should address the real needs of the people. Positive discrimination in favour of the disadvantaged is needed when providing access to the nation's resources. Community information services aim at providing information to the community to help members cope with their designated roles within that community. The information provided covers all aspects of life to assist 
Table 2 South African public library service: current characteristics

\begin{tabular}{|c|c|}
\hline Basic components of system & Characteristics \\
\hline 1 Library model & $\begin{array}{l}\text { - Western library model } \\
\text { - Appropriate for developed communities; } \\
\text { - Inappropriate for developing communities, with low levels of education and literacy, } \\
\text { poor socio-economic conditions and an oral tradition. } \\
\text { - Infrastructure } \\
\text { - Well developed in former white areas, nearly non-existent in other areas; } \\
\text { - Provincial library system prioritising disadvantaged } \\
\text { areas. } \\
\text { - Authorities still reluctant; } \\
\text { - Access to networks. } \\
\text { - Collections } \\
\text { - Represent mostly Western values; } \\
\text { - More appropriate material, for example, adult literacy material, and literature in in- } \\
\text { digenous languages receiving attention. New local publishing bodies specialise in adult literacy } \\
\text { material; } \\
\text { - Number of indigenous languages hamper publishing for local needs. } \\
\text { - Community information service } \\
\text { - Still not widely practised, although a feature of resource centres and community libraries. }\end{array}$ \\
\hline 2 Needs assessment & $\begin{array}{l}\text { - Needs analysis still inadequate; } \\
\text { - More research required. }\end{array}$ \\
\hline 3 Staff training & $\begin{array}{l}\text { - Training mainly geared to skills required in developed communities; } \\
\text { - Awareness of need for changes in curricula to accommodate needs of black communities; } \\
\text { - Non-traditional skills addressed but not yet adequately; } \\
\text { - Profession divided on issue of literacy training. }\end{array}$ \\
\hline 4 Library co-operation & $\begin{array}{l}\text { - Relatively well-established, sophisticated systems exist; } \\
\text { - Interlibrary lending facilitated through joint catalogues, databases and networking; } \\
\text { - State Library co-ordinates interlibrary lending. }\end{array}$ \\
\hline 5 Alternative services & $\begin{array}{l}\text { - Two main types of alternative models: } \\
\text { - Resource centres; } \\
\text { - Community libraries. } \\
\text { - Aim at empowering disadvantaged communities; } \\
\text { - Forge close links with the community; } \\
\text { - Collections based on community needs. Consist mostly of alternative material, for } \\
\text { example pamphlets, newspapers and audio-visual material; } \\
\text { - Services rendered according to needs expressed by the community. Level of services } \\
\text { determined by users. }\end{array}$ \\
\hline
\end{tabular}

community members to cope with day-to-day problems and to improve their quality of life (Legoabe 1995:16). This type of information encompasses:

- survival information: relating to aspects, such as health, childcare, housing, finance, legal and political rights;
- citizens action information: needed for effective participation in the social, political, legal and economic process, either as an individual or as part of a group (Lor in Louw 1993:20; Donohue in Pienaar 1995:15). This kind of information has been necessitated by the 
growth and specialisation of bureaucracies, as well as the increase in, and complexity of the legislation regulating our everyday lives (Pilkington \& Morrison 1996:6).

The materials are mainly of a transitory nature, for example, leaflets, posters, pamphlets and newspaper cuttings. In mainly illiterate communities resources should also include audio-visual material. A main resource is that of repackaged material for which the librarian is responsible.

Community information services call for a different kind of staff member to provide the information service. Stilwell (1991a:20,24) sees the ideal candidate as a person coming from the community, keeping a high profile in his/her community by being an active member in community activities. This will enable the librarian to forge a close relationship between him/herself and the community. Active involvement between the librarian and the user is imperative, as it leads to a better understanding of the nature of the user's problem. Good communication and motivational skills are necessary to ensure involvement of the whole community (Ferguson [1987?]:9). This interaction will result in staff not merely being passive mediators between the published sources and the public, but becoming active participants in the creation of new information sources (Kambule 1992:43).

New skills should also include methods in which information is to be disseminated to the community. Information and skills should be shared to demystify and challenge the traditional power relations in society (Stilwell 1991b:318). Kantumoya (1992:34) advocates easy access to information for all-and-sundry, but especially the lower social groups, against whom information networks have always been biased. He maintains that information in Africa is being disseminated through methods inaccessible to the common man, be it in the rural or urban areas. The National Consumer Reference Council (in Kantumoya 1992:34) has the following to say about the lack of access to information by the majority of people:

'People will not be able to get their due as citizens of present day society unless they have continuous access to the information which will guide them through and where necessary, the advice to help them translate that information into effective action, and unless they get their due, they are unlikely to recognise the reciprocal obligation that all citizens have to the society'.

The unbiased dissemination of information, using means and methods known and accessible to the man in the street, would thus be a major task of the librarian. This would entail different skills in actively finding the correct information, repackaging and disseminating it, skills which are not normally used in the traditional public library sector.

Community information services can be provided from a library, or from a separate centre. It can take several forms, ranging from information and referral, direct service, and back-up service to self-help services (Pilkington \& Morrison 1996:7).

Close co-operation with other organisations and programmes operating in the community is seen as essential. The community library forms only a part of the overall information network. It needs to rely on the co-operation of the other agencies to assist the library in information gathering processes. It also needs to rely on these agencies to refer their clients to, when mere provision of information is not enough to solve a problem. Community libraries cannot operate in isolation (Stilwell in South African libraries must adapt or die, 1991:6).

Table 3 summarises the basic characteristics of community libraries as presented in the literature.

\section{Pinetown Public Library system}

The Pinetown Public Library system consists of a main (Western model) library with four branches, and ten community libraries established since 1992 (Van der Merwe 1995:26) which are accountable to the Chief Librarian for all activities and programmes offered by them. Only the five oldest community libraries were included in the study because the others were still in the process of establishing themselves in their respective communities.

All the libraries in the system are financially supported by the local authority, and the entire system is affiliated to the Provincial Library Service from which it receives its book stock. Staff from each library visit the Provincial Library to select and exchange books (Van der Merwe 1995:26).

\section{Community library development}

The establishment of the community libraries was the direct result of requests made by the respective community organisations and residents' associations. The many students in need of a library service, the distance between the residences of the communities and the Pinetown Library, as well as the prospect of instilling a reading culture in the high school students were cited as reasons for the wish that library services should be established (Klaarwater Residents Association 1992). It was also envisaged that these libraries would be used by adult community groups (Mpola Coordinating Committee 1992). After several representations to the Borough of Pinetown, conditional approval was given to become involved in the establishment of community libraries (Community library development [n.d]). The first community libraries to be established were St Wendelins, Klaarwater, Mpola and Tshelimnyama which opened their doors to the public in May 1992. In 1993 Thornwood was established. These five community libraries were included in the study.

The members of the communities were not local ratepayers, therefore the services could initially not be financed from Borough funds. Funds for salaries and operating costs were obtained from the KwaZulu-Natal Provincial Administration's Community Service Branch. Since 1994 the Borough has taken responsibility for the financial costs, and salaries 


\section{Table 3 Nature of community libraries}

\begin{tabular}{|c|c|}
\hline Components & Characteristics \\
\hline I Establishment & $\begin{array}{l}\text { - Established at request of community; } \\
\text { - Needs full co-operation from community. }\end{array}$ \\
\hline 2 Governance & $\begin{array}{l}\text { - Participative management in the form of a community committee; } \\
\text { - Participation ensures relevant services. }\end{array}$ \\
\hline 3 Finance & - Funds provided by community/sponsors. \\
\hline 4 Aims & $\begin{array}{l}\text { - Pro-active service; } \\
\text { - Empowerment of all community members, especially the disadvantaged; } \\
\text { - Making all community resources available to all community members. }\end{array}$ \\
\hline 5 Users & $\begin{array}{l}\text { - Can determine membership - either open to whole community, or restrictions can be } \\
\text { imposed. }\end{array}$ \\
\hline 6 Information & $\begin{array}{l}\text { - Directly linked to the everyday lives of community members; } \\
\text { - Two kinds of information: } \\
\text { - survival information, for example, on health and childcare; } \\
\text { - citizens action information, for example, information concerning social, political and legal } \\
\text { rights; } \\
\text { - Mainly alternative material, for example, pamphlets, brochures, newspaper clippings and oral } \\
\text { material; } \\
\text { - Pro-actively provides information to the disadvantaged in the community, to help them cope } \\
\text { with problems in their daily lives. }\end{array}$ \\
\hline 7 Services & $\begin{array}{l}\text { - Active interaction between librarians and users; } \\
\text { - Pro-active approach necessitates different forms of service, for example, } \\
\text { - Information and referral: } \\
\text { - Linking the correct service with the correct user. } \\
\text { - Direct service: } \\
\text { - Face-to-face contact between the librarian and user to solve the user's problem; } \\
\text { - Back-up service: } \\
\text { - Based on active involvement of library staff in community activities and services that can } \\
\text { make the community aware of sources that can solve their problems; } \\
\text { - Self-help: } \\
\text { - Teaching the users to become self-reliant. } \\
\text { - Each community determines the type of service rendered. }\end{array}$ \\
\hline 8 Staff & $\begin{array}{l}\text { - Different qualities than those of traditional librarians, are required from staff-members, for } \\
\text { example, } \\
\text { - Staff are known to, and trusted by the community; } \\
\text { - Good communication and motivational skills are essential; } \\
\text { - Staff are able to repackage information. }\end{array}$ \\
\hline 9 Co-operation & - Active co-operation exists between library and other community organisations. \\
\hline
\end{tabular}


are paid by the Borough of Pinetown. The Provincial Library Service provided book stock, furniture, shelves and some audio-visual equipment.

Some of the libraries were initially housed in temporary buildings until proper accommodation could be supplied. The Durban Functional Region provided the funds for the building of Klaarwater and alterations to St. Wendelins. The local Joint Services Board approved funds for the building of Mpola (Community Libraries of Pinetown South [n.d]). Funds for activities and special programmes must be generated by the community library staff themselves (Van der Merwe 1995:26).

Each community library started with a complement of two volunteers. These volunteers came from each community, and in most cases had no previous experience of library work.

Training and supervision of the staff are provided on a one-to-one basis by the Pinetown Public Library. They receive in-house training for a three- to four-week period, and from there on are assisted on a personal basis when problems arise. Aspects covered in this period include: issue desk duties, weeding, mending of material, how to do shelf reading, how to run a story-hour, and cataloguing and classification. These are all skills taught to librarians functioning in traditional public libraries. It is not quite clear to what extent skills such as good communication and co-operation with individuals and the community; repackaging of information; and marketing the library services using innovative methods, skills commonly associated with community libraries, are covered.

In an effort to create better co-operation between the central library and the community and branch libraries, a senior branch librarian was appointed in January 1994. The job description of this staff member includes daily contact with the libraries to help with problem-solving and training, to conduct inspections, write progress reports and render general assistance (Van der Merwe 1995:26).

Combined staff meetings are currently held on a monthly basis. During these meetings problems can be discussed with the Chief Librarian (Van der Merwe 1995:26).
Community librarians are responsible for their own activities, workshops and story hours. They are also expected to assist with community needs assessment and this knowledge is used when selecting books for their libraries from the Regional Provincial depot.

Membership has shown considerable growth since the establishment of the libraries, as illustrated in Figure 1.

The only library that had a negative growth rate in any year since 1992 was Mpola in 1995. Much of this can be attributed to the fact that the library space was extremely cramped at that time, and it had no study space for students.

Liaison with community leaders still seems to be a problem, as the Residents Committees seem to be changing all the time. The librarians all experience problems with the civic organisations in their communities, in the sense that they want to prescribe to the librarians how they should run their libraries. Involvement from community members themselves in the running of the library also varies from library to library.

Two of the community libraries, Thornwood and Tshelimnyama, experience serious problems with lack of space. The rooms in which the libraries are housed are very small, and staff do not have enough space for the processing of books and library activities such as story hours. Study space for students and scholars are also very restricted.

\section{Pinetown Community Library survey}

The librarians questionnaire and interview schedule were designed to test the community libraries against the norms presented in Table 3. The questions were formulated to obtain information regarding the following:

- type of material used and the extent to which the material is circulated;

- reasons why the libraries are used by the community;

- training received by the librarians in running a library;

- activities offered by the library to the community;

- extent to which the libraries cater for the information needs of the illiterate;

- community involvement in the running of the library, and of the librarians' involvement in community affairs.

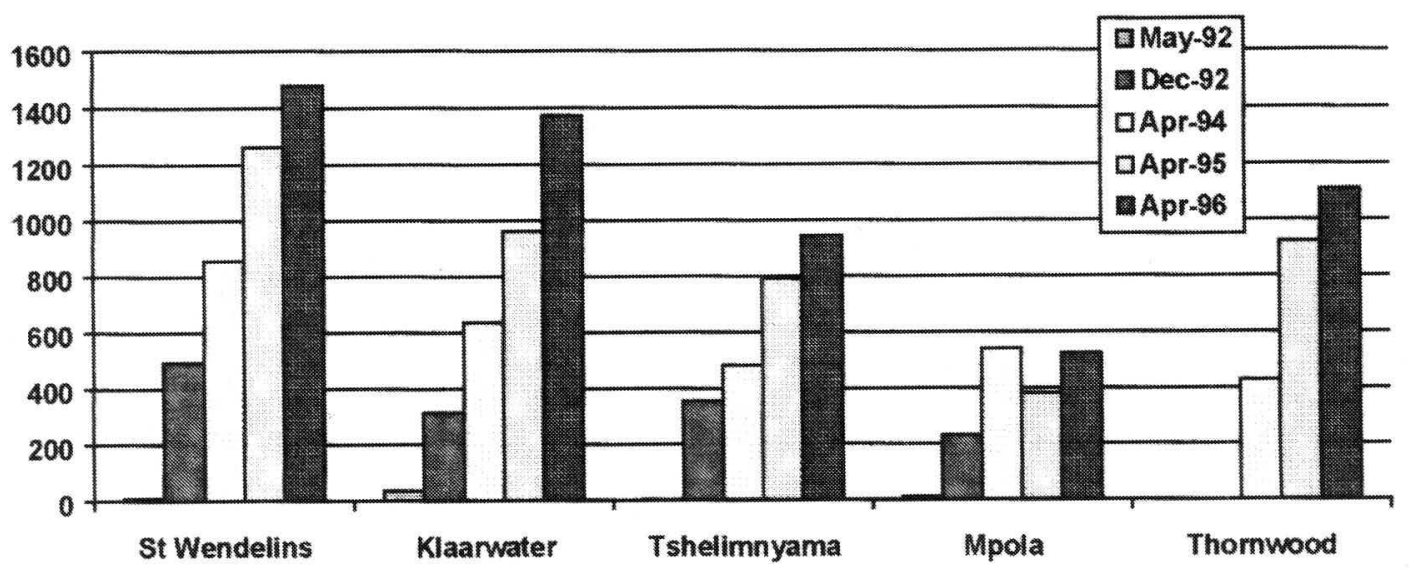

Figure 1 Community library membership 
The community questionnaire was compiled to:

- obtain personal information about members of the community, both library members and non-members, for example, age, sex, educational level and employment;

- establish the extent of reading among the community members, as well as their preferred language type of material;

- determine reasons for non-use of the community library;

- establish the extent of community library utilisation, as well as the type of material used to find information;

- determine the attendance of activities organised by the community library, as well as the need for certain activities normally associated with community libraries.

\section{Problems experienced}

Several problems were experienced during the empirical testing of the community library programmes. With the translation of the questionnaires to and from Zulu some of the original meaning of sentences could have been lost, resulting in not eliciting the response anticipated.

Concentrating the community survey on a central shopping area where people were readily available, could have resulted in not all the communities being represented evenly.

The use of a ranking system for some of the questions also proved to be a problem especially in the community questionnaire. A large number of the respondents did not follow the instructions correctly, and therefore the questions requiring ranking showed many discrepancies. The feedback that was received was however regarded as useful for identifying certain trends.

\section{Interpretation of librarian's questionnaire and interviews}

From the answers provided by the librarians, as well as the literature provided by the Chief Librarian of the Pinetown Public Library, it is clear that the community libraries function as part of the Pinetown Public Library system which is accountable to the local authority. Although the request for the establishment of these libraries originated from the communities themselves, apart from some initial consultation with the community leaders, the communities are not in any other way responsible for the management of the libraries. The community does not contribute either in a financial sense or in an administrative or organisational sense.

In the cases where some community involvement does exist, it is fairly limited, for example, at Tshelimnyama the Library Committee members have been trained as assistants to assist the staff whenever one of the staff members is absent, and at St. Wendelins the Committee members actively try to promote library services. At Thornwood it is mainly the literacy teachers who are involved in the library programme. The only other contribution by the community is through the suggestion box at St. Wendelins which offers the community the opportunity to air their views. Autonomous existence and accountability to the community therefore do not exist. This contradicts Fairer-Wessels and Machet's view (1993:106) that a community library is one owned, sustained and maintained by members of a disadvantaged community.

In most cases the location of the community libraries is relatively central and they are fairly accessible to the people in the communities, although not all of them are central to the abodes of the people as suggested by Stilwell (South African libraries must adapt or die, 1991:6). Where the community libraries form part of a community centre, especially if an activities hall forms part of the library, it enhances its chances of becoming a focal point in the community's social activities. This concept is also recommended by Iwuji (1990:58). Where the libraries stand isolated, for example, in Mpola, Tshelimnyama, and to some extent, St. Wendelins, they do not form part of the community life. The library thus loses much of its ability to play a meaningful role in the development of the disadvantaged in the community.

The materials offered by these libraries do not differ substantially from those offered by the traditional public library. According to Fairer-Wessels (1988:3) and Shillinglaw (1986: 40) the traditional public library is mainly print-based, and aims at self improvement and leisure reading, thus presupposing a reading public. The Pinetown community libraries concentrate less on leisure reading than traditional public libraries but the information on offer in the community libraries are still mostly print-based. Although the librarians all expressed satisfaction with the subjects covered by the available material, scanning of the shelves indicated that the materials available were those found in any traditional library, with very little, if any, information available on issues concerning the day-to-day life of the community. The material available mainly represented the Western culture, making its applicability remote to the circumstances of people living in Third World conditions.

Although the librarians said they were taught repackaging of information, none applied that skill, with the result that the illiterate are left with no way of getting information other than through the oral medium, either from the librarian (an unfamiliar source for most), or from family and friends. An investigation into the audio-visual, as well as the audio materials revealed that most of these were not informative by nature but rather aimed at leisure. The videos contained some informative material, mainly based on the National Geographic series, which is hardly the kind of information needed in South African developing communities. Pamphlets, although available in some of the libraries, were not up to date nor available in large numbers. They can also not be taken home. According to the librarians these pamphlets are a popular medium with the members visiting the library, thus attention should be paid to the expansion of this component. Newspaper cuttings were not in evidence, although most of 
the libraries indicated the existence of cuttings. The librarians and community members should be made aware of the importance of this information source, especially for community and current information. Librarians should be taught how to organise and maintain this kind of material for the benefit of their users.

Community information services are offered by all the libraries. This is a service which characterises community libraries, although many traditional public libraries are also in the process of adopting it as part of their services. Information is regularly updated through the active canvassing of the librarians. Referrals are part of the service offered by the Pinetown Community Libraries, although the librarians do not physically accompany the enquirer to the referred destination. As a result the librarian is not in a position to determine whether the enquirer could actually satisfy his/her information need. In disadvantaged communities, follow-up is important, as empowerment of the people can only be achieved when they obtain the correct information.

The staff complement is very small, and therefore personalised service can unfortunately not be rendered on a full-time basis. At the same time, empowerment and upliftment of the community are closely related to giving practical assistance to those who are unable to do certain things for themselves, for example, the illiterate and unemployed. Ways and means to render such services should therefore be sought.

All the community libraries, with the exception of Mpola Community Library, are actively trying to be of practical assistance to the disadvantaged in the community, through teaching literacy classes, or by making facilities available for these classes, or by assisting the unemployed to gain skills. The librarians indicated that they were actively involved with community organisations. This involvement is also used to gather information, and to forge contacts which can be utilised if need be to assist a user with an information need when the opportunity arises. The librarians also use these contacts to advertise their library's services.

No restrictions are placed on the type of material available in the library. The stock however mainly consists of material obtained from the Provincial Library Services, and therefore reflects the selection policy of this institution. No trace could be found of material, for example, to inform people about political matters, of legal material informing people about their rights, or material on contentious issues like abortion. An interlibrary lending system is in place, but from the interviews it became clear that it is mainly used to request textbooks and study material.

Changed staff attitudes are vital for the success of community libraries. For example, good communication and motivational skills, skills in repackaging of information, skills to obtain community information and to be able to utilise community sources to refer people to when necessary, contribute to attitude changes and should be instilled during training (Nassimbeni, Stilwell \& Walker 1993:40). The community librarians received only in-house training for a relatively short period of time. The information supplied indicated that the training received was mainly based on the traditional chores normally performed in a public library. Although all the librarians claim to have been taught how to repackage information, no evidence of such activities could be found. They also did not mention that they were taught specific skills like, for example, how to effectively communicate with a person needing advice, or needing guidance in a certain matter, which are communication skills closely associated with a community information service.

All the community librarians are active members of their communities. Most have lived in the community for a long time, and some were even born and bred in the community. Despite being well known, some librarians mentioned that they experienced difficulty in being accepted by the community, and had to use their involvement in community organisations to win the trust of the community.

\section{Interpretation of community questionnaire}

Generally speaking the communities appeared to be reading communities, as most of the respondents indicated that they read in their spare time. This could be due to the fact that school children and students represented a significant percentage $(47.7 \%)$ of the respondents.

Zulu and English were indicated as being the most popular languages. The popularity of these languages, especially those materials written by African authors, was confirmed by the community librarians. What was interesting was that books were the preferred medium, while newspapers and magazines were not as popular. This coincides with the findings of Johnstone (1988:129). However, in a study done in Botswana, Mchombu and Mtunyatta (1988:30) found that the main reason for people visiting the village reading rooms was to read magazines and newspapers. It would thus seem that community libraries in South Africa are mainly, used as study centres, and sources for finding information. With newspapers arriving a day or two late in the community libraries it is perhaps not surprising that they are a less popular medium.

There still seems to be much ignorance concerning the library and the services it offers. It can either be attributed to unsatisfactory marketing of the library, or apathy on the part of community members. Most of the community members indicated that they would support programmes like literacy classes, and a community information service, if offered by the library. These services exist in the libraries, or are supported by the libraries, yet members of the public seem generally unaware of them.

There also seems to be a need in communities for activities like crafts classes, talks, and video shows; and space for community meetings and extra curricular activities should also be provided. Most of the community libraries, however, are hampered by the lack of a community hall. Where an activities hall exists, crafts classes are offered, mainly for the benefit of the women. This perhaps explains why so many respondents indicated that they seldom or never attended these classes. The kinds of crafts the community would like to 
master should be determined to attract as many members of the community as possible.

Although a fair number of the respondents indicated that they found the information they were looking for either always or occasionally when visiting the library, it is alarming that most of the time many (30.2\%) did not find what they were looking for. This could indicate that either the material in the collection is not what the community needs, or it could indicate that the users are too shy to ask for assistance from the librarians. Better communication between the librarians and the users would help to rectify the problem, and the collection should also be developed to support the real needs of users.

A significant percentage of the respondents (71.6\%) indicated one or more visits within a two-week range. This tendency was confirmed during the authors' visits, when a constant movement of users was observed. The libraries therefore seem to play an important role in the lives of many of the residents in the communities, albeit then only to supply a convenient study space. Non-awareness of the library and its services were indicated as the main reasons for non-use which indicates inadequate marketing. In a community which includes many illiterates the librarians should concentrate on marketing methods that will also reach that part of the community, for example, by making use of audio-visual media like radio and TV to advertise their services. Librarians should also exploit opportunities offered at blood donor clinics, school meetings and local authority meetings to market the library by word of mouth. Attention should also be given to the other reasons for non-use, that is unsuitable library hours, reading difficulties, and uninteresting material, as it could be an indication that other members of the communities could experience the same problems.

As mentioned above attention should be paid to communication between librarians, users and other community members. Although library committees do exist, it would seem that they are only partially involved in giving advice on certain library matters, for example, renovations and literacy classes. The exception is Thselimnyama where active involvement is encouraged, and the users are actually deployed in the library as assistants when needed. This results in lively community participation in the running of the library and its services. At the two libraries without any community involvement the librarians seemed dejected by the lack of interaction. As user involvement is imperative for the success of community libraries, this is an aspect that needs urgent attention.

The results of the questionnaires and interviews were used to evaluate the Pinetown Community Libraries individually according to the following characteristics:

- community involvement in establishment;

- financial support provided by community;

- community involvement in management of library;

- library support for upliftment programmes;

- provision of a community information service;

- co-operation with other organisations to provide service to users; and
- needs analysis to determine service needs.

A checklist for these characteristics presented in Table 4, was developed to indicate levels of satisfaction. Table 5 contains the results of the evaluation. If a characteristic is not met, it is indicated by a $x$. If the characteristic is met, but unsatisfactorily, that is, not sufficiently active, it is indicated by a *. If it is met at a satisfactory level, that is, sufficiently active, it is indicated by $* *$.

Table 5 indicates that St. Wendelins and Tshelimnyama performed well in four out of seven categories (10* each). Thornwood and Klaarwater in two categories with an overall score of $8^{*}$ and $7 *$ respectively. The common weakness according to the norms is the lack of community financial support. The level of satisfaction of community members with regard to certain aspects of the community libraries services, for example, the community information service, could not be determined on the information collected. It is possible that according to them, this service did not function at a satisfactorily level. This aspect could be a topic for further research.

\section{Conclusion}

The evaluation of the performance of each community library shows that these libraries are still in a transition phase. Through co-operation with other organisations the community libraries are starting to break out of the isolated mould which became a trademark of public libraries, and have become more active participants in the information transfer process. The focus has also shifted from service to the educated elite to involvement in efforts to uplift the disadvantaged in the communities, thus resulting in a whole new attitude towards the library user. One can therefore conclude that the Pinetown Community Libraries have moved away from the traditional public library service model, and at least two, namely St. Wendelins and Tshelimnyama, are well on their way to offering their communities a pro-active community library service. Much more work remains to be done especially in Mpola, with regard to community financial support, and community involvement especially with regard to upliftment programmes.

For these libraries to become community libraries in the full sense of the word, the following aspects should be addressed:

- The community should become more involved, especially with regard to the planning of new services, recommendations regarding different types of information sources, assistance with obtaining oral information from members of the community, and the use of community members for activities such as storytelling, crafts classes and music and drama classes.

- Open communication channels should be created. Regular open community meetings, providing an opportunity for feedback on the services and for suggestions regarding services for which the community has a need, should be held. These meetings can also be used to educate the community on what can be expected from the service, 


\section{Table 4 Community library checklist}

\begin{tabular}{ll}
\hline $\begin{array}{l}\text { Established by } \\
\text { community }\end{array}$ & - If community actively asked for the establishment, either through correspondence or through meetings with \\
local authority officials - **
\end{tabular}
community

- If libraries were proposed by local authority, and established after some consultation with members of the community - *

Community financial support

Community involvement

Upliftment

Community information service

Co-operation with other organisations

Needs analysis
- Libraries built without any consultation with communities - $\mathrm{x}$

- Communities paid for all expenses - **

- Communities made some form of contribution towards funding the service - *

- Communities made no contribution towards funding of services - $\mathrm{x}$

- Communities contributed to three or more of the activities listed - **

- Active involvement in delivering a service, for example, as assistants or library janitors;

- Active library committee;

- Community members involved in publicising/marketing library services;

- Community input through suggestions or meetings as to what services they expect;

- Involvement of community members in presenting library programmes, for example youth programmes and story hours.

- Community involvement in fewer than three of above-mentioned activities - *

- Community involvement in none of the above-mentioned activities - $\mathrm{x}$

- Active involvement in three or more of the following activities - **

- Involvement in literacy classes;

- Involvement in improving lot of unemployed's plight through co-operation with skills training programmes;

- Arrangement of, or involvement in craft or cookery classes;

- Presentation of repackaged material conveying information in a simple understandable manner to the illiterate;

- Providing access to all information resources necessary to cope with daily survival.

- Involvement in fewer than three of above-mentioned activities - *

- Involvement in none of above-mentioned activities - $\mathrm{x}$

- Provision of three or more of the following services associated with a community information service - **

- Referral;

- Advice;

- Practical assistance with certain tasks for example, the completion of forms;

- Provision of community information.

- Provision of fewer than two services associated with a community information service - *

- No service provided - $\mathrm{x}$

- Active co-operation with organisations in community - **

- Co-operation on ad hoc basis - *

- No co-operation - $\mathrm{x}$

- Continuous analysis done using a variety of methods, also including non-users -**

- Occasional analysis done using a variety of methods, including only library members - *

- No analysis done - $\mathrm{x}$ 
Table 5 Community library performance

\begin{tabular}{|c|c|c|c|c|c|c|c|}
\hline \multirow[t]{2}{*}{ Name of library } & \multicolumn{7}{|c|}{ Community library norms } \\
\hline & $\begin{array}{l}\text { Established by } \\
\text { community }\end{array}$ & $\begin{array}{c}\text { Community } \\
\text { financial support }\end{array}$ & $\begin{array}{l}\text { Community } \\
\text { involvement }\end{array}$ & Upliftment & $\begin{array}{c}\text { Community } \\
\text { information } \\
\text { service }\end{array}$ & $\begin{array}{l}\text { Co-operation with } \\
\text { other organisations }\end{array}$ & $\begin{array}{c}\text { Needs } \\
\text { analysis }\end{array}$ \\
\hline St .Wendelins & $* *$ & $\mathrm{x}$ & $* *$ & $*$ & $* *$ & $* *$ & * \\
\hline Mpola & $* *$ & $\mathrm{x}$ & $\mathrm{x}$ & $\mathrm{x}$ & $* *$ & $*$ & * \\
\hline Klaarwater & $* *$ & $x$ & $\mathrm{x}$ & $*$ & $* *$ & $*$ & * \\
\hline Tshelimnyama & $* *$ & $x$ & $* *$ & $*$ & $* *$ & ** & * \\
\hline Thornwood & $* *$ & $\mathrm{x}$ & * & $*$ & $* *$ & * & * \\
\hline
\end{tabular}

and how to go about ensuring that a high standard of service is maintained.

- A publicity campaign should be conducted to introduce the library and its services to the community. This should be followed by a community meeting where community involvement is advocated.

- Own funds for every community library should be dealt with as a matter of urgency. Due to the current economic situation in South Africa, most community libraries cannot function autonomously. However, the system of obtaining all materials from the Provincial Library Service does not necessarily allow scope for meeting specific community needs through the provision of alternative materials. Own funds will allow scope for acquiring community specific information. Community fund-raising events could generate funds for the library and provide an opportunity for community involvement in the spending of these funds.

- Staff should be trained to develop skills that will enable them to become pro-active agents of information transfer. They should learn how to anticipate needs, in order to act even before such needs are expressed. They should also be taught how to go out into the community, using knowledge gained to bring the library to the people, instead of adopting a sit-and-wait attitude. A demonstration programme utilising expertise within the library system as well as in the broader professional, and also local community, would facilitate continued education for community library staff. The librarians have to be recruited from the communities served which means that they come from the information-poor sector of society, and therefore need to experience first hand how a successful programme operates. A well-planned demonstration programme could well be the key factor in the upgrading of these libraries to fully fledged community library services.

\section{References}

Astbury, R. 1993. The public library of the twenty first century: the key learning and information institution in the community? In Revision of the Unesco public library manifesto '72. ed. by C.J.M. Gomes:63-67.
Banach, E. 1989. The role of the public library in a changing society. Artes Natales, 7(11):5-11.

Barnes, E.A. 1994. Library outreach services in South Africa. M.Bibl dissertation, Rand Afrikaans University, Johannesburg: RAU.

Bekker, S. \& Lategan, L. 1988. Libraries in black urban South Africa: an exploratory study. South African journal of library and information science, 56(2):63-72.

Chijioke, M.E. 1989. Public library services as information networks: Nigeria in the twenty-first century. Journal of librarianship, 21(3):174-185.

Cillié, R.M. 1995. Co-operation between librarians and development agents. Meta-info bulletin, 4(3):2-6,7.

Community Libraries of Pinetown South (pamphlet). [n.d.].

Community library development (pamphlet). [n.d.].

Fairer-Wessels, F.A. 1988. The role of the public in developing communities: the promotion of literacy. Free State libraries, April-June:2-4.

Fairer-Wessels, F.A. \& Machet, M.P. 1993. The development of alternative information services for the black community in South Africa. Mousaion, 11(1):100-111.

Ferguson, S. [1987?] Resource mobilization for the implementation of the rural community resource centre. Paper presented at the COMLA workshop, New Delhi, August 27th28th:1-13.

Iwuji, H.O.M. 1990. Librarianship and oral tradition in Africa. International library review, 22:53-59.

Johnstone, I.Y. 1988. Die openbare biblioteek as instrument tot ontwikkeling met verwysing na enkele swart ontwikkelende gemeenskappe in Natal - 'n verkennende ondersoek. M.Biblverhandeling, Universiteit van Pretoria, Pretoria.

Kagan, A. 1982. Literacy, libraries and underdevelopment - with special reference to Tanzania. Africana journal, 13(1-4):1-23.

Kambule, A. 1992. Rural libraries and resources - whither a democratic information base? Matlhasedi, 11(2):40-43.

Kantumoya, A. 1992. Public libraries and community information service in Africa. African journal of libraries, archives and information science, 2(1):33-38.

Klaarwater Residents Association. 1992. Letter written to the Chief Librarian requesting establishment of a library service, 2 February.

Legoabe, N. 1995. Community information services (CIS): a powerful instrument for the RDP. Free State libraries, JanMarch:16-17.

Louw, A. 1993. Some responses of libraries to changing user and community requirements. South African archives journal, 35:14-23.

Martin, W.J. 1989. Community librarianship: changing the face of public libraries. London: Clive Bingley. 
Mchombu, K.J. 1991. Which way African librarianship? IFLA journal, 17(1):26-38.

Mchombu, K.J. \& Mutanyatta, J. 1988. The Village Reading Room pilot project: an evaluation report. Information trends: news magazine, 1(1):28-34.

Mostert, B.J. 1997. Community libraries: the concept and its application: with particular reference to the Pinetown community libraries. M.Bibl dissertation, University of Zululand, KwaDlangezwa.

Mpola Coordinating Committee. 1992. Letter written to the Town Clerk requesting establishment of a library service, 21 February.

Nassimbeni, M., Stilwell, C. \& Walker, C. 1993. Education and training for library and information work: and analysis of the current South African situation with a view to the way forward. Innovation, 6:31-44.

Pienaar, R.E. 1995. Survival information and public libraries. IFLA journal, 21(1):15-18.

Pilkington, A. \& Morrison, J. 1996. Community information centres in public libraries. KWAZNAPLIS, Jan/Feb:6-9.

Raseroka, K. 1994. Rural services to developing communities. Artes Natales, 13(1):3-6.

Shera, J.H. 1972. The foundations of education for librarianship. New York: Becker \& Hayes.

Shillinglaw, N. 1986. The role of the public library in the development of South Africa. South African journal of library and information science, 54(1):38-44.
Shillinglaw, N. \& Thomas, W. 1988. The information society. Craighall: A.D. Donker.

South African libraries must adapt or die. Artes Natales, 10(3):47.

Stilwell, C. 1991a. Community libraries: a viable alternative to the public library. Progressive librarian, 4(Winter):17-27.

Stilwell, C. 1991b. The community library as an alternative to the public library in South Africa. M.Inf dissertation, University of Natal, Pietermaritzburg:

Stilwell, C. 1992. The resource centre forums: democratic and alternative information networks for South Africa.

International information and library review, 24:213-220.

Sturges, P. \& Neill, R. 1990. The quiet struggle: libraries and information for Africa. London: Mansell.

Todaro, M.P. 1989. Economic development in the Third World. 4th. ed. New York: Longman.

Van der Merwe, M. 1995. Gemeenskapsbiblioteke werk! Cape librarian, 39(3):26-27.

Williams, P. 1988. The American public library and the problem of purpose. New York: Greenwood Press.

Wilson, P. 1977. A community elite and the public library: the uses of information in leadership. Westport: Greenwood Press.

Zaaiman, R.B., Roux, P.J.A. \& Rykheer, J.H. 1988. The use of libraries for the development of South Africa. Pretoria: University of South Africa. 